\title{
TASAWUF FILOSOFIS DAN FILSAFAT SUFISTIS DALAM EPISTEMOLOGI IBN TUFAIL
}

\author{
Muliadi \\ Ushuluddin UIN SGD Bandung \\ Jln. Ciawitali no.9 Kebon Kapas Kulon rt. 01 rw. 14 Waluya Cicalengka Bandung. Hp. 081931192236. \\ E-mail: khalef1muliadi@yahoo.com
}

\begin{abstract}
ABSTRAK
Banyak jalan menuju Roma. Unkapan ini bisa juga kita gunakan dalam mendapatkan kebenaran. Banyak jaln menuju kebenaran (the Ultimate/Infinitife). Karya Ibn Tufail telah menggambarkan bagaimana pertemuan antara filsafat dan ajaran agama berteman secara harmonis. Keduanya memiliki jalan yang berbeda namun menemukan kebenaran yang sama (al-haqq). Karya ini menggambarkan kepada semua orang bahwa filsafat bisa berselimut dengan tasawuf dan tasawufpun tidak harus alergi dengan filsafat, karena keduanya bersaudara dan saling melengkapi.
\end{abstract}

\section{KATA KUNCI}

Filsafat; Tasawuf; Kebenaran (Al-Haqq)

\section{DOI: https://doi.org/10.15575/saq.v1i2.1435}

\section{A. PENDAHULUAN}

Dunia filsafat, dari awal keberadaannya, khususnya epistemologi diwarnai oleh pergesekan-pergesekan keras antar rasionalisme, empirisme dan intuitisme, atau antara akal dan hati, yang tidak jarang mendatangkan korban sepihak. Hal ini terjadi baik dalam sejarah filsafat Barat maupun dalam sejarah filsafat Timur (Islam). Socrates dihukum Mati karena dituduh sebagai "provokator", ia bersikeras untuk rnengajukan pertanyaan-pertanyaan kepada mereka yang dianggap rnengetahui tentang hal tertentu yang sudah diterima sebagai pegangan umum ataupun oleh masing -rnasing individu, namun setelah mendapatkan jawaban teryata banyak yang keliru dan tidak sesuai dengan kebenarankebenaran yang logis dan masuk akal yang diyakini oleh Socrates. Galileo disiksa, Bruno dibakar di atas unggunan api, karena mereka dianggap menentang kepercayaan yang telah dianut dan dipegang oleh khalayak umum saat itu. Spinoza dijuluki sebagai orang atheis dan Descartes juga terpaksa melarikan diri untuk rnenyelamatkan jiwanya . Sedangkan dalam sejarah filsafat Islam tidak lepas dari pergesekan yang mengerikan antara filsafat dan agama, ditambah lagi dengan ikut campurnya beberapa penguasa yang melarang tersebamya ajaran filsafat.

Dalam perkembangannya, filsafat Islam tidak terlepas dari tekanan-tekanan yang dilakukan oleh kaum agamawan ataupun ulama konserpatif, yang sampai pada klimaks dari sikap mereka yaitu mengharamkan adanya filsafat termasuk pembelajarannya. Konsekuensi dari sikap itu maka tidak jarang para ulama bahkan para penguasa yang mendukung ulama tadi atau sebaliknya, membakar buku-buku filsafat, buku-buku logika, dan buku-buku lain yang berkaitan dengan filsafat. Hal ini mereka lakukan, karena mereka menganggap bahwa dengan adanya ajaran-ajaran filsafat bisa menggoyahkan bahkan merubah iman masyarakat yang sudah kuat dan kokoh. Hal ini bisa kita lihat misalnya pada masa pemerintahan dinasti Umayyah di Andalusia, pada masa kekuasaan Hisyam bin Hakam, pada masa pemerintahan dinasti Murobitun dan dinasti Muwahhidun. Pada saat itu Ibn Rusd juga diasingkan dan beberapa dari para menteri yang menjadi sahabatnya seperti Ibn Zaidun, Ibn Hotib, dan Ibn Zaniruh . Maka tak heran kalau al-Hallaj dihukum gantung oleh 
penguasa saat itu karena mengaku sebagai alHaq.

Fakta sejarah juga menunjukan, bahwa pertikaian antara filsafat dan agama juga dimotori oleh para filosof ataupun oleh para teolog sendiri, al-Ghazali yang mengkafirkan para filosof dalam beberapa rnasalah dalam bukunya Tahafutul falasifah yang kemudian dibantah oleh Ibn Rusd dengan bukunya Tahafutut tahafut. Hal ini berarti bahwa wacana epistemologi yang dikaitkan dalam bidang pemahaman keagamaan, juga tidak lepas dari pergesekan-pergesekan yang sangat mengenaskan dan sangat disayangkan.

Dari fakta di atas menunjukan bahwa wacana epistemologi filosofis jarang sekali jalan beriringan atau jalan bergandengan dengan epistemologi iman atau theologis. Ketika iman atau theologi yang lebih menonjol maka filsafat tersisihkan, dan sebaliknya ketika filsafat lebih diutamakan maka tak jarang wacana teologi lebih dikesampingkan.

Lalu apa hubungannya antara pergesekan filsafat dan agama dengan efistemologi seperti yang telah dipaparkan dimuka? Cakupan atau ruang pembahasan efistemologi adalah masalah pengetahuan dan segala yang terkait di dalamnya temasuk masalah dari manakah datangnya ilmu pengetahuan, bagaimana ia dirumuskan, diekspresikan dan dikomunikasikan? Apakah pengalaman indrawi penting bagi semua tipe pengetahuan? Apakah peran rasio di dalam ilmu pengetahuan? Bagaimana peran intuisi dalam mendapatkan pengetahuan? Apakah perbedaan satu konsep dengan konsep yang lain? Apakah akal tidak boleh menyentuh masalah keagamaan atau iman?.

Kalau kita berbicara mengenai efistemologi maka mau tidak mau akan terkait juga dengan masalah pengetahuan atau kebenaran itu sendiri, karena manusia tidak hanya terbatas pada jasmaniahnya saja. Tuntutan kebenaran pun tidak hanya terbatas pada pemenuhan hasrat jasmaniahnya saja ataupun akalnya saja, tetapi menelusuri kebenaran tersebut sampai pada tingkat yang lebih tinggi yaitu kebenaran yang bersifat rohani atau ilahi. Di sinilah letak posisi strategis efistemologi dalalm menggapai kebenaran yang tinggi, apakah indra atau

akal lebih berperan untuk menggapainya? A pakah hati atau intuitif manusia yang lebih dominan atau cocok dari yang lainnya?

\section{B. IBN TUFAIL}

Nama lengkap ibn Tufail adalah Abu Bakar Muhammad bin Abdul Malik bin Muhammad bin Muhammad bin Tufail. Ia lahir di Wadi Ash (sekarang Cadik) pada awal abad ke XII. Setelah belajar ilmu obat, sastra, ilmu falaq, dan filsafat ia berpraktek di Granada dan sebagai dokter pribadi merangkap wazir dari sultan Abu Ya'qub Yusuf dan putranya Abu Yusuf Ya'qub pada masa kekuasaan dinasti Muwahhidun. Pada tahun 1182 ia diganti oleh ibn Rusd dalam jabatannya. Ia meninggal dalam usia lanjut di Maroqish pada tahun 1185 dan salah satu buku yang ditinggalknnya adalah Hay ibn Yaqzan ( hidup anak sadar ) .

Kisah Hay ibn Yaqzan ditulis oleh ibn Tufail dalam bahasa arab kira-kira pada tahun 1169, pada tahun 1671 diterjemahkan dalam bahasa latin dengan teks arabnya oleh Edward Pocock dengan judul Philosophus Autodidactus. Pada tahun 1674 terbit terjemahan dalam bahasa inggris dari bahasa latin oleh George Keith. Pada tahun 1676 dari bahasa latin ke bahasa inggris oleh George Achwell. Pada tahun 1708 muncul terjemahan lain Hay ibn Yaqzan oleh Simon Ockley dan dicetak lagi pada tahun 1731. Muncul juga terjemahan inggris oleh Paul Bromle tahun 1904 dengan judul The Awaking Of The Son .

Terjemahan pertama dalam bahasa Ibria, namun tak dikenal penerjemahnya, kemudian diedit oleh Moses Nerbone tahun 1349. Terjemahan dalam bahasa Jerman oleh Eichonn dan disebarkan di Berlin tahun 1783. Pada tahun 1900 tersebar terjemahan di Sarraoqustah oleh P.Pons dan disusul oleh cetakan berikutnya pada tahun 1905 di Mesir. Pada tahun 1920 diterjemahkan dalam bahasa Perancis oleh Leon Gauther. Secara umum kisah ini dibagi menjadi tiga bagian dan tiap bagian terdiri dari beberapa sub. Bagian pertama adalah pendahuluan, yang berisi alasan ditulisnya novel ini. Kemudian 
rnenyebutkan ide-ide pokok para filosof pendahulunya seperti ibn Bajah, ibn Sina, alFarabi, dan al-Gazali. Setelah rnenampilkan ide-ide pokok para filosof tersebut, ibn Tufail rnenyodorkan alirannya yang disebutnya sebagai al-Hikmah al-Masyriqiah ( Ada beberapa pendapat dalam menafsirkan kata ini 1. Yang dimaksudkannya adalah filsafat Timur, alasannya karena adanya lawan kata masyrik yaitu maghrib, maksud mereka yakni yunani. 2 . Yang dimaksud yaitu Hikmah Timur dari dinasti Islam, karena Ibnu Sina, Farabi, dan Persia terletak di bagian timur dari Bagdad sebagai ibu kota dinasti Abasiyah. 3. Dan ada juga yang menyebutnya sebagai hikmah iluminatif. Namun yang dimaksud dalam Novel ini adalah yang nomor tiga bila kita lihat dari rangkaian isinya), dengan mengungkapkannya dalam bentuk kisah alegoris.

Bagian kedua adalah khusus mengenai Hay ibn Yaqzan yang dibagi dalam enam sub. Sub pertama menceritakan asal Hay ibn yaqzan dalam pulau kosong. Asal Hay ini dalam dua versi, yaitu: Hay sebagai anak yang lahir secara geografis: Hay lahir dari sebongkah tanah yang sudah berabad-abad lamanya, karena sering kena panas dan dingin akhirnya seakan - akan tanah itu tempat menyatu antara dua kekuatan tadi, dan pada bagian terdalam dari tanah itu menyerupai manusia, yang ditiupkan padanya ruh, maka lahirlah manusia di daerah itu yang disebut Hay bin Yaqzan.

Yang kedua, Hay lahir sebagai anak dari kedua orang tuanya: yaitu seorang putri yang memiliki saudara dan menjadi penguasa pada pulau di sebelah pulau tempat kelahiran Hay, raja tersebut mempunyai teman namanya Yaqzan, ia menikahi putri tersebut dengan cara merahasiakanya dari saudaranya tadi, hingga ia hamil dan melahirkan Hay. Karena takut diketahui oleh saudaranya, maka Hay dimasukan dalam peti dan dihanyutkan ke laut sambil pasrah dan memohon kepada Allah supaya anak tersebut dilindungi dan dikasihi. Terdamparlah anak tadi di pulau kosong tersebut .

Sub kedua, menceritakan tentang pendidikan Hay, yaitu pendidikan pertama yang didapatkannya dari obsevasi indrawi, eksperimen, dan komparasi, Hay saat itu berumur 7 sampai 21 tahun.

Sub ketiga, menceritakan perkembagan pemikiran Hay dari pengetahuan indrawi dan eksperirnen - (empirisme ) menjadi pengetahuan akal (rasionalisme) yang dibangun atas dasar eksperimen dari alam dan benda-benda mati.

Sub keempat, menceritakan perkembagan pemikiran Hay dari rasionalisme menuju penghayatan pada langit, alam, dan segala isinya. Pada saat ini Hay berumur 35 tahun.

Sub kelima, Hay menyimpulkan dari pemikiran dan perenungannya tadi bahwa dirinya memiliki jiwa rohani yang berbeda dari badan (jism) yang dengannya ia menemukan hakekat (esensi), bukan hal kebendaan yang tak bisa disentuh atau diraba dan tak mungkin menggambarkannya.

Sub keenam, menceritakan tentang urutan emanasi, pada tahap ini Hay berumur 50 tahun.

Bagian ketiga, menceritakan dua tokoh bantu (tokoh secunder) yaitu Asal dan Salaman, yang tinggal di pulau sebelahnya. Asal adalah seorang sufistik sedangkan Salaman adalah seorang tekstualis dalam memahami kitab suci.

Untuk menemukan hakekat dari sebuah kebenaran agama, Asal pergi ke pulau tempat Hay untuk berkhalwat, di sana Asal bertemu dengan Hay dan memunculkan dialog antara keduannya yang menggambarkan kesamaaan pemahaman dalam agama.

Hay dan Asal bersepakat untuk pergi ke pulau asal Asal dan mengajarkan ilmu ma'rifat tersebut pada masyarakat umum (kaumnya Salaman), namun mereka berdua tidak berhasil kecuali sedikit saja dari mereka yang mau ikut dan memahami ajaran tersebut.

Hay dan Asal akhirya kembali ke pulau tempat tinggal Hay yang pertama untuk beribadah secara tulus dan ikhlas dan merekapun menemukan kembali hakekat kebenaran yang sudah diperoleh sebelumnya (al-Haq).

\section{ANALISA EPISTEMOLOGI KISAH HAY IBN YAQZAN}


Pada bagian ini penulis mengutip secara ringkas beberapa bagian dari kisah ini yang menunjukkan segi-segi epistemologinya, sebagai berikut:

Empirisme Induktif (observasi, indrawi, dan experimen )

Ketika Hay yang kesehariannya hidup dengan binatang, memperhatikan semua jenis hewan yang berada di sekelilingnya terutama anak-anak rusa yang baru lahir, mereka tidak memiliki kecepatan lari, kekuatan bertarung, dan tak memiliki senjata untuk mempertahankan diri seperti tanduk, taring, cakar, dan yang sejenisnya.

Kemudian ia memperhatikan dirinya sendiri yang telanjang, tak mempunyai senjata, lamban dalam melangkah, tidak memiliki tenaga yang cukup, agak lemah, dan jikalau ada binatang liar lain menyerang dan menganiayanya, maka ia tak mampu melawan ataupun melarikan diri. Kemudian ia melihat anak rusa tadi sudah memiliki tanduk yang sebelumnya tiada, dan menjadi kuat, sedangkan ia tidak melihat hal itu pada dirinya. Hay memikirkan hal tersebut namun tak mengetahui sebabnya dan ketika melihat pada binatang yang lain tak satupun serupa dengannya.

Melihat kekurangan tersebut pada dirinya, maka Hay menjadikan dedaunan sebagai penutup badannya, daun tersebut ditempelkan di muka dan di belakang hingga tertutup selurah anggota badannya sampai dedaunan tadi mengering dan berjatuhan dari badannya satu persatu. Hay juga menjadikan ranting sebagai tongkat, alat untuk mempertahankan dirinya dan keberadaannya sehingga ia merasa lebih dari binatang lainnya, dari itu ia melihat banyak manfaat dan kelebihan dari kedua tangannya .

Ketika lemah dan letih yang sering menghinggapi rusa (ibu Hay), hingga pada akhirnya mengalami kematian. Ketika Hay mengetahui hal ini, ia bingung campur sedih seraya memanggilnya layaknya ketika masih hidup dengan suara yang lebih keras, namun hal itu sia-sia belaka. Maka, Hay merneriksa kedua telinganya, semua indranya, dan anggota tubuhnya namun ia tak menemukan satupun yang dirasa menyebabkan kematian ibunya, maka terbersit dalam pikirannya bahwa yang menyebabkan hal ini adalah sesuatu yang metafisik yang berada dalam jasad. Jika ia ada, maka hewan akan hidup seperti biasa dan jika sebaliknya maka hewan tersebut akan mati. Sampai akhinya ia berpikiran bahwa sesuatu itu berada di tengah-tengah dari anggota tubuh hewan.

Hay melakukan pembedahan di dada rusa dengan batu keras dan dengan belahan bambu yang mirip pisau, Hay pertama-tama menemukan limpa, namun bukan itu yang ia harapkan, sampai ia menemukan pasangannya yang berada di sebelah samping yaitu hati yang berada persis di tengah dada, Hay memeriksa hati itu namun iapun tak menemukan sesuatu yang ganjil padanya sampai ia mengeraskan dan menekan genggamannya hingga jelas baginya bahwa dalam hati terdapat dua lubang yakni lubang sebelah kanan yang berisi cairan darah, dan lubang sebelah kiri yang hampa, kosong, dan tak didapatkan sesuatu apapun. Hay mencerca tubuh dan meremehkannya dan bertanya-tanya tentang sesuatu yang meninggalkan lobang sebelah kiri tersebut yang menyebabkan tubuh bergerak atau sebaliknya mati seketika.

Karena bangkai rusa sudah membusuk, maka Hay menguburkannya (caranya menguburkan diketahui dari pengalamannya ketika ia melihat dua ekor gagak yang bertengkar sampai akhimya salah satu diantaranya kalah dan meninggal, gagak yang menang dan masih hidup menggali lubang dan menguburkan temannya tadi, maka terdetik bagi Hay bahwa ibunya lebih berhak untuk dikuburkan), namun kebigungan Hay belum terjawab tentang lubang yang berada di sebelah kiri itu. Di sela-sela kebingungannya itu ia melihat api menyala di pinggir pantai karena gesekan-gesekan dahan- dahan kering. Iapun mernbakar ikan dan lain-lainnya dari ikan laut, saat itu Hay bertanya-tanya apakah sesuatu yang berada di lubang sebelah kiri itu mirip dengan api ini? Karena sifatnya sama yaitu selalu ke atas. Maka Hay melakukan experimen pada hewan liar yang masih hidup dan membelah dadanya hingga sampai pada 
hati, Hay mendahulukan lubang sebelah kiri dan membelahnya, ia melihat lubang yang

kosong tadi dipenuhi oleh hawa, yang mirip seperti kabut putih. Hay memasukan jarinya ke lubang tadi dan merasakan hawa tadi agak kepanas-panasan rnaka matilah hewan tadi seketika.

Dari eksperimen tadi maka Hay berkesimpulan bahwa hawa yang kepanaspanasan tadi adalah yang menggerakkan semua binatang . Keinginan Hay untuk mengetahui lebih lanjut mengenai anggota tubuh hewan dan susunan - susunannya dimana semuanya tergantung pada roh tadi sesuai dengan fungsinya atau peran masing-masing anggota tubuh yang tergantung pada satu surnber tadi yang dihubungkan melalui syaraf, sedangkan syaraf tersebut meminta bantuan kepada otak, dan otak tadi meminta bantuan kepada hati (roh). Di kepala banyak roh karena ia tempat berbaginya beragam jenis aktivitas. Pada saat ini Hay telah berumur 21 tahun. Hubungan antara roh dan badan ini bisa kita bandingkan dengan teorinya Descartes, dimana roh dan badan saling mempengaruhi oleh kelenjar kecil yang letaknya berada di bawah otak kecil (glandula phiealis).

\section{RASIONALISME INDUKTIF}

Pada kesempatan yang lain Hay memeriksa semua bagian dari alam baik hewan dengan berbagai jenisnya, tumbuh-tumbuhan, tambang -tambang, batu-batuan, tanah, air, kabut, salju, hujan, es, kobaran api, dan panas maka ia menemukan dari semua itu sifat yang bermacam-macam, ada yang berbeda dan ada yang sama dalam gerakan-gerakannya.

Roh adalah satu, layaknya air yang berbeda karena tempatnya, meskipun warnanya berbeda namun esensinya tetap satu yaitu air. Setelah observasi yang panjang ia membandingkan antara hewan dan tumbuh-tumbuhan, dimana keduanya sama-sama membutuhkan makanan, berkembang, namun hewan memiliki kelebihan dalam indra, gerakan, dan pengenalan. Sedangkan tumbuh-tumbuhan dalam bentuknya yang lain yaitu seperti perubahan arah bunga yang menghadap matahari (pemekaran). Adapun benda-benda mati mengalami perubahan dari satu kondisi ke kondisi lain seperti air menjadi uap, panas menjadi dingin, dll.

Sedangkan adanya makna tambahan dari hal-hal bendawi, seperti pemuaian, penampakan, kedalaman, gerakan ke atas atau sebaliknya membawanya pada kesimpulan bahwa setiap peristiwa ada yang menjadikannya atau sebab yang pertama. Dari sini Hay mulai merindukan sebab yang pertama dan berusaha untuk mengetahuinya dan meninggalkan hal-hal bendawi yang cepat rusak, sampai ia memikirkan hal-hal samawi. Sampai di sini Hay telah berumur 28 tahun .

Hay mulai mengagumi langit dan alam beserta isinya hingga ia mengetahui bahwa langit beserta bintang-bintangnya merupakan jenis jisim karena tidak lepas dari sifat-sifat bendawi seperti panjang, penampakan, kedalaman, terbatas dan terjangkau . Maka Hay ingin mengetahui bentuknya, ia melihat matahari, bulan, dan bintang -bintang. Semua terbit dari ufuk timur dan tenggelam di ufuk barat, sedangkan jarak Hay dan planet-planet tersebut ke atau dari penglihatannya sama, baik pagi, siang ataupun sore, maka ia berkesimpulan bahwa bentuk planet adalah seperti bola, dan ia juga berkesimpulan bahwa planet-planet tersebut kesemuanya adalah satu kesatuan yang tak terpisahkan seperti hewan dan anggota badannya.

Pemikiran Hay berpindah pada: apakah alam itu baru atau qodim, jika ia memegang yang kedua padahal ia telah menyakini bahwa setiap jism mustahil baginya tiada terbatas, namun jikalau yang pertama, maka ia mesti punnya pencipta, maka ia berkesimpulan bahwa zat alam adanya lebih akhir dari zat Tuhan. Namun tidak dalam hal waktu, karena awal alam tidak diketahui, sampai pikirannya mentok pada bahwa pencipta alam tidak bisa diketahui dengan indra, tidak bisa dihayalkan, dan tidak bisa disifati dengnan sifat jism dan tidak mungkin mengalir pada jism, karena hal seperti itu adalah sifat jism, maka penggerak alam bukan jism. Sampai saat ini Hay telah berurnur 35 tahun .

Setelah ia sampai pada tingkatan ini, maka ia bertanya-tanya pada dirinya bagaimana saya 
bisa mengetahui alam dan dengan kekuatan apa, saya bisa mengetahui Wajibul Wujud (Yang Ada)? Sampai ia berkesimpulan bahwa zat dirinya yaitu roh yang dengannya ia bisa mengetahui yang tidak memiliki sifat jasmani dan yang tidak boleh disifati dengannya dan esensi zatnya adalah yang denannya ia mengetahui yang Ada, atau Yang Mutlak yang tidak akan pernah lupa, musnah, dan ia selalu abadi.

Secara rasio bahwa sesuatu yang diketahui ataupun dilihat, jika ia lebih lengkap, lebih sempurna, lebih indah, dan lebih baik, maka dengan sendirinya keiriduan dan keinginan terhadapnya lebih banyak. Dan obyek yang harus diketahui dan yang agung tersebut adalah Allah. Barang siapa yang tidak dapat mengetahuinya maka rasa sedihnya lebih besar dan jika sebaliknya orang-orang yang telah mengetahui dan telah menyaksikannya (Ma'rifat dan Musyahadah) maka dia akan selalu dalam kenikmatan yang tidak berkeputusan .

\section{E. INTUITIF}

Pada tahap berikutnya, Hay dengan intuisinya bisa dengan mudah sampai pada kebenaran yang universal yaitu Wajibul Wujud melalui meditasi atau berhalwat pada saat-saat tertentu. Jalan ini pada akhirnya menjadi pilihan utama Ibn Tufail atau dengan kata lain ia lebih mengutamakan tasawuf daripada filsafat, meskipun pada awal mulanya kebenaran tersebut berasal dari rasionalisme reflektif. Pada akhir kisah Hay Ibn Yaqzan, Ibn Tufail mendeskripsikan bahwa masyarakat secara umum tidak bisa diajak ataupun diajar untuk menekuni bidang-bidang yang bersifat "metafisik", karena kebenaran-kebenaran yang terkandung di dalamnya lebih banyak diungkapkan melalui permisalan atau perumpamaan-perumpamaan (alegoris).

Hay mengajak Asal pergi ke desa Salaman dan mengajarkan penduduknya tentang kebenaran yang telah didapatkan dan disepakati bersama Asal yang ahli dalam bidang syariat, namun apa yang didapatkan oleh mereka berdua bukannya pengikut ataupun sambutan yang hangat, tetapi cercaan dan hinaan bahkan dianggap sebagai pembawa kebohongan (bid'ah). Hanya sebagian kecil aja yang mampu memahami apa yang diajarkan oleh Hay. Untuk itu ia meninggalkan desa tersebut dan kembali ke pulau kosong dimana ia berasal, meneruskan halwat atau semedinya dan ia sering mendapatkan pencerahan ruhani.

\section{F. TUJUAN NOVEL}

Setelah mengetahui beberapa kutipan di atas, maka kita bisa menebak bahwa tujuan novel tersebut adalah ingin menunjukkan pada kita bahwa manusia dengan akal murninya bisa sampai kepada kebenaran. Otto Horrassowits mengatakan, bahwa tujuan dari novel Hay ibn Yaqzan adalah bahwa filsafat sekaligus dengan agama harus dipahami dengan tepat, tapi bahwa aspek-aspek eksoteris dan esoteris agama dan filsafat itu merupakan ekspresi kebenaran kekal yang sama yang disingkapkan kepada setiap individu sesuai dengan kemampuan mereka.

Lebih lanjut ia mengatakan, bahwa secara filosofis, risalah itu merupakan suatu pemaparan yang hebat tentang teori Ibn Tufail mengenai pengetahuan, yang berupaya menyelaraskan Aristoteles dengan NeoPlatonis di satu pihak, dan al-Gozali dengan ibn Bajjah di pihak lain. Al-Gozali sangat kritis dan dogmatis terhadap rasionalitasnya Aristoteles, tetapi ibn Bajjah adalah pengikut sejati Aristoteles. Ibn Tufail mengikuti jalan tengah, menjebatani jurang pemisah antara

kedua belah pihak itu. Sebagai seorang rasionalis, dia memihak ibn Bajjah dalam

melawan al-Gozali dan mengubah tasawuf menjadi rasionalisme. Sebagai seorang ahli tasawuf dia memihak al-Gozali dalam melawan ibn Bajjah dan mengubah rasionalisme menjadi tasawuf. Ekstase merupakan bentuk tertinggi pengetahuan, tapi jalan menuju pengetahuan semacam itu diperlicin dengan mengembangkan nalar, diikuti dengan pemurnian jiwa melalui praktek-praktek kezuhudan. Metode-metode al-Gozali dan ibn Tufail keduanya sebagian sama, tetapi, tidak seperti al-Gozali, ekstase ibn Tufail ditandai dengan tekanan kepada Neo Platonik. Al-Gozali yang setia kepada sikap 
teologis-mistisnya, menganggap ekstase sebagai sarana untuk melihat Tuhan, tapi bagi ibn Tufail, sang filosof, visi indah mengungkapkan akal aktif dan rangkaian sebab Neo-Platonik sampai pada unsur-unsurnya dan kembali lagi kepada diri.

\section{G. KESIMPULAN DAN TANGGAPAN ATAS NOVEL}

Bila kita telah secara mendalam, dan kita teliti secara serius, novel ini sangat berpengaruh di dunia Barat, dimana jauh-jauh sebelum abad modern dengan metode dialektis kritisnya ibn Tufail telah memberikan sumbangan yang sangat besar bagi ilmu pengetahuan, pembahasan tentang astronomi sudah dibahasnya jauh sebelum Galileo Galilei ataupun Copernicus meneliti tentang astronomi. Begitujuga dengan metode cogito ergo sumnya Descartes, dan semua aliran aliran empirisme maupun rasionalisme pada abad modern sampai sekarang telah banyak berhutang pada ibn Tufail.

Dalam masalah keagamaan, novel ini telah memberikan gambaran yang sangat jelas bagi kita semua, dimana semua orang tidak perlu lagi saling memojokkan antara satu kelompok keagamaan dengan kelompok lainnya, antara teolog dengan filosof, antara satu agama dengan agama lain, karena jika yang dituju adalah kebenaran (yang Benar/ al-Haqq) maka banyak jalan untuk menggapainya. Hal ini telah digambarkan dalam alur kisah ini, terutama pertemuan antara tiga tokoh di dalamnya yaitu Hay, Asal, dan Salaman.

Karya ibn Tufail ini secara tidak langsung telah menggambarkan kehidupan filsafat dan saudaranya (aliran literalis/para teolog dan fuqoha). Kedatangan filsafat ke dunia Islam tidak diterima secara langsung, bahkan mendapatkan perlawanan semenjak kedatangannya tersebut. Perlawanan ini tidak hanya pada level konsep, namun beberapa filosof dan karya-karyanya mendapatkan perlakuan yang tidak baik. Banyak buku dari fara filosof yang dihanyutkan bahkan dibakar.

Keadaan ini seringkali diperparah juga oleh dinasti. Ketika yang memimpin dinasti adalah raja yang suka terhadap ilmu pengetahuan maka filsafat mendapatkan ruang untuk berkembang dan sebaliknya, ketika dinasti dipimpin oleh raja yang dekat dengan para teolog dan para fuqoha maka filsafatpun mendapat celaan dan perlakuan yang tidak menyenangkan. Berangkat dari keadaan ini yang berkepanjangan dalam perkembangan sejarah Islam, maka Ibn Tufail dengan karyanya ini menunjukkan bahwa ajaran tentang filsafat perlu diajarkan melalui karya alegoris, bukan secara "terbuka".

\section{H. DAFTAR PUSTAKA}

AM, Goichon, Hay ibn Yaqzan, dalam B. Lewis, Et.al, (ed) The Enciyclopedia of Islam. Vol. 111, Leiden, 1978

Bakker, J.W.M. Sejarah Filsafat Islam, Kanisius, Yogyakara, 1987. Hadiwijono, Hadiwiyono,Harun, Sari Sejarah Filsafat Barat 2, Kanisius, Yogyakarta, 1980.

Horrassowits, Otto, History of Muslim Philosophy, terjem. Parafilosofmuslim, ed:M.M, Syarif,M.A, Mizan, Bandung, 1962

Kattsoff, Louis O,Horrassowits, Otto, Element of Philosophy, terjem. Pengantar filsafat, Soejono Soemargono, Tiara Wacana, Yogyakarta, 1992.

Rokabi, Jaudat, Fil adabil Andalusi, Darul Maarif, Mesir 1960

Tufail, Abu Bakar bin, Hay ibn Yaqzan, ed, Alber Naser Nadr, cetakan kedua, Darul Masyriq, Bairut, Libanon, 1986.

Bakker, J.W.M, Sejarah Filsafat Islam, Kanisius, Yogyakarta 1978 